\title{
APPLYING NANOPARTICLES FOR TREATING GIARDIA INFECTION: A SYSTEMATIC REVIEW
}

\author{
HAMDAN I. ALMOHAMMED ${ }^{1}$, AISHAH E. ALBALAWI ${ }^{2}$, HADEEL AL SADOUN ${ }^{3}$, NAVID BAKHTIARI ${ }^{4}$, MORTEZA \\ AMRAEI $^{5}$, ALI MOGHADDAM ${ }^{6}$, GHAIDAA RAHEEM LATEEF AL-AWSI ${ }^{*}$
}

${ }^{1}$ Department of Microbiology and Parasitology, Almaarefa University, Riyadh 11597, Saudi Arabia, ${ }^{2}$ Faculty of Science, University of Tabuk, Tabuk 47913, Saudi Arabia, ${ }^{3}$ Department of Medical Laboratory Technology, Faculty of Applied Medical Sciences, King Fahd Medical Research Center, King Abdulaziz University, Jeddah, Saudi Arabia, ${ }^{4}$ Faculty of Pharmacy, Ayatollah Amoli Branch, Islamic Azad University, Amol, Iran, 5Department of Health Information Technology, School of Paramedical Sciences, Lorestan University of Medical Sciences, Lorestan, Khorramabad, Iran, ${ }^{6}$ Student Research Committee, Lorestan University of Medical Sciences, Khorramabad, Iran, ${ }^{7}$ Department of Radiological Techniques, Al-Mustaqbal University College, Babylon, Iraq Email: ghaidaa.rahem@mustaqbal-college.edu.iq

Received: 18 Jun 2021, Revised and Accepted: 31 Jul 2021

\section{ABSTRACT}

At present, chemotherapy with some drugs such as nitroimidazoes derivatives is the preferred treatment for giardiasis. However, these agents are associated with adverse side effects ranging from nausea to possible genotoxicity. The present investigation was designed to systematically review the in vitro, in vivo, and clinical studies about the efficacy of nanoparticles against giardiasis. The study was carried out based on the 06-PRISMA guideline and registered in the CAMARADES-NC3Rs Preclinical Systematic Review and Meta-analysis Facility (SyRF) database. The search was performed in five English databases, including Scopus, PubMed, Web of Science, EMBASE, and Google Scholar, without time limitation for publications around the world about anti-Giardia effects of all organic and inorganic nanoparticles without date limitation in order to identify all the published articles. The searched words and terms were "Giardiasis", "Giardia lamblia", “Giardia intestinalis", "Giardia duodenalis", "nanoparticles", "nanomedicine", "in vitro", in vivo", and "clinical trial". Out of 312 papers, 10 papers, including 4 in vitro (40.0\%), 5 in vivo (50.0\%), and 1 in vitro/in vivo $(10.0 \%)$ up to 2021 met the inclusion criteria for discussion in this systematic review. The most common type of nanoparticles was metal nanoparticles (5 studies, 50.0\%) such as silver, gold, etc., followed by organic nanoparticles such as chitosan nanoparticles (4 studies, $40.0 \%$ ). The results of this review study showed the high efficacy of a wide range of organic and non-organic NPs against giardiasis, indicating that nanoparticles could be considered as an alternative and complementary resource for treating giardiasis, since they have no significant toxicity. However, more studies are required to elucidate this conclusion, especially in clinical systems.

Keywords: Giardia lamblia, Giardia intestinalis, Giardia duodenalis, Nanoparticles, Nanomedicine, In vitro, In vivo, Clinical trial

(c) 2021 The Authors. Published by Innovare Academic Sciences Pvt Ltd. This is an open-access article under the CC BY license (https://creativecommons.org/licenses/by/4.0/) DOI: https://dx.doi.org/10.22159/ijap.2021v13i5.42466. Journal homepage: https://innovareacademics.in/journals/index.php/ijap

\section{INTRODUCTION}

Giardia lamblia (syn. Giardia intestinalis, Giardia duodenalis) is a flagellated protozoan parasite that commonly causes giardiasis or acute and watery diarrhea [1]. The disease is considered as one of the main waterborne and foodborne diarrhea around the world, which infects about 280 million people annually [2]. Humans are generally infected through ingesting contaminated water and food, as well as person-to-person transmission. The most people at risk for giardiasis are children in day-care settings, child-care workers, institutionalized individuals, and travelers in endemic areas via ingestion of contaminated or recreational water, immunodeficiency, cystic fibrosis, and oral-anal sex [2, 3]. Although the disease is mostly asymptomatic, a number of clinical symptoms such as diarrhoea, steatorrhea, nausea, abdominal pain, vomiting, and weight loss are presented in the infected children [4].

At present, chemotherapy with some drugs such as metronidazole (MTZ), tinidazole, and nitazoxanide is the preferred treatment for giardiasis [5]. However, according to recent reports, these agents are associated with adverse side effects ranging from nausea and metallic taste in the mouth to psychosis, carcinogenesis, and possible genotoxicity [6]. In recent years, an alarming increase in resistance to the conventional agents with nitroimidazoles such as MTZ has been reported in various parts of the world. However, the promising strategies for this drug treatment failure are monotherapy with some effective drugs such as quinacrine as well as combined therapy with some agents [7]. Consequently, it is necessary to find new alternatives with high efficacy and low toxicity for treating giardiasis.

Over the last years, nanotechnology has been introduced as a relatively new field of science and technology that deals with nanometer-sized material for medical purposes [8]. This innovative technology has been used in various fields of sciences through a combined approach. Nowadays, an increasing number of applications and products containing nanomaterials have been considered [8].

Use of nanotechnology for medical purposes has been named nanomedicine and is described as e applying nanomaterials for diagnosis, monitoring, control, prevention, and treatment of diseases [9]. Although a wide range of in vitro, in vivo, and clinical studies have reported the antimicrobial effects of some inorganic nanoparticles (such as metal and metal oxide) and organic nanoparticles (peptideand polymer-based nanoparticles such as cationic peptides, synthetic cationic polymers, chitosan, etc.) $[10,11]$; but there is no documented report on the drug resistance of microbes, especially parasites, to nanoparticles. However, broad adoption of nanoparticles for giardiasis is at present hampered by uncertain findings of the investigation, not always sufficiently powered. Our study aimed to systematically review the existing literature (in vitro and in vivo) in the field of nanomedicine for giardiasis treatment.

\section{MATERIALS AND METHODS}

\section{Search strategy}

The current study was carried out using 06-PRISMA guideline and registered in the CAMARADES-NC3Rs Preclinical Systematic Review and Meta-analysis Facility (SyRF) database [12]. The search was performed in five English databases, including Scopus, PubMed, Web of Science, EMBASE, and Google Scholar without time limitation for publications worldwide related to anti-Giardia effects of organic and inorganic nanoparticles without date limitation in order to identify all the published articles (in vitro, in vivo, and clinical studies). Studies in any language were entered into the search step if they had an English abstract. The words and terms were used as a syntax with specific tags of each database. The searched words and terms were: "Giardiasis", "Giardia lamblia", "Giardia intestinalis", "Giardia duodenalis", "Nanoparticles", "Nanomedicine", "In vitro", and "In vivo" (fig. 1.). 


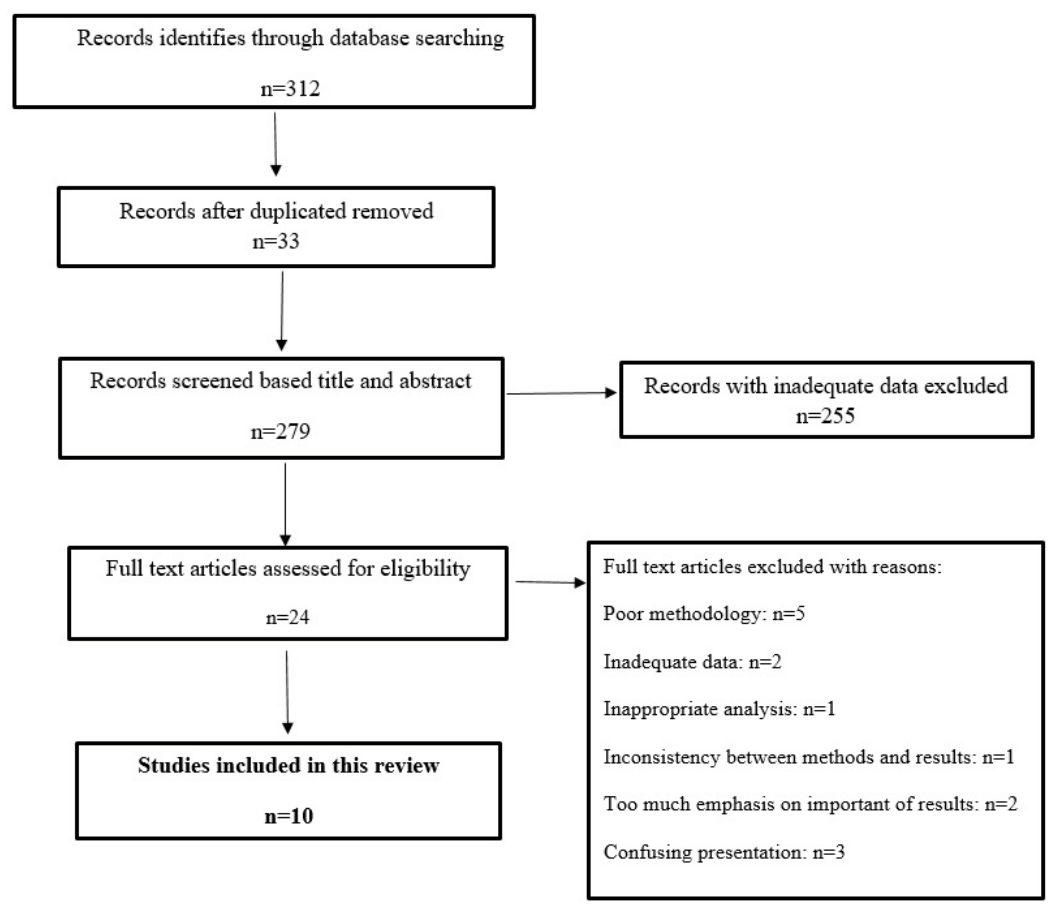

Fig. 1: Flowchart describing the study design process

\section{Quality assessment and article selection}

First, the studies were imported to EndNote X9 software (Thomson Reuters, New York, NY, USA) and duplicate studies were deleted. Afterwards, three independent authors examined the title and abstract of the studies and the relevant studies were included for further analysis. The same authors carefully read the studies and the eligible studies with adequate inclusion criteria were selected.

\section{Exclusion criteria}

The studies with inadequate information, abstracts submitted in congresses without full texts, failure to match methods with results, and the incorrect interpretation of the results was excluded from the current study.

\section{Inclusion criteria}

Inclusion criteria of this study were the articles evaluating the effects of nanoparticles on giardiasis, emphasizing the design of various forms of nanoparticles containing drugs and other pharmaceutical formulations against giardiasis.

\section{Data extraction}

Three independent authors extracted information from the selected articles and, if needed, the differences were resolved by the corresponding author. The extracted data included nanoparticle type, in combination or loaded with other drugs, type of study, parasite form, condition, concentration, time of used and obtained findings, and references.

\section{RESULTS AND DISCUSSION}

Out of 312 papers, 10 papers including 4 in vitro (40.0\%), 5 in vivo (50.0\%), and 1 in vitro/in vivo (10.0\%) up to 2021 met the inclusion criteria for discussion in this systematic review with the data extracted, as presented in table 1 . The most common type of nanoparticles was metal nanoparticles (5 studies, $50.0 \%$ ) such as silver, gold, etc., followed by and organic nanoparticles such as chitosan nanoparticles (4 studies, 40.0\%). In this study, we investigated the effect of different nanoparticles on Giardia parasite and giardiasis disease, put the obtained information in a table, and categorized it. According to the nanoparticles mentioned in the table, we classified them into two categories of organic and inorganic nanoparticles and explained their effect on Giardia.

\section{Organic nanoparticles}

\section{Chitosan}

Chitosan (poly-(b-1/4)-2-amino-2-deoxy-D-glucopyranos) and its derivatives due to having some exceptional properties such as minimum toxicity, biocompatibility, and biodegradability, have been broadly used as an immunomodulatory, anticancer, anti-nociceptive, antioxidant, anti-inflammatory, and antimicrobial agent [23-26]. Todays, it has been proven that chitosan-based biomedical drugs such as nanoparticles, hydrogels, coatings, suspensions, powders, membranes, films, etc. are able to affect the pharmaceutical and biomedical effects of these agents [27, 28]. In recent years, several studies have reported the antimicrobial effects of chitosan and its derivatives against a broad spectrum of pathogenic viruses, bacteria fungi, as well as helminthic and protozoan parasites [29-31]. Yarahmadi et al. (2016) demonstrated the considerable chitosan nanoparticles (CNPs) synthesized by Penicillium viridicatum and $P$. aurantiogriseum at the doses of $50,100,200$, and $400 \mu \mathrm{g} / \mathrm{ml}$ on Giardia cysts, whereas CNPs at the dose of $400 \mu \mathrm{g} / \mathrm{ml}$ and after 180 min exposure killed $100 \%$ Giardia cysts [13].

In addition, Chabra et al. (2019) reported that chitosan and nanochitosan at the concentrations of 100,200 , and $400 \mu \mathrm{g} / \mathrm{ml}$ significantly reduced the $G$. lamblia trophozoite, ranging from 89 to 100 , after $3 \mathrm{~h}$ exposure in vitro. The findings also showed that the oral administration of chitosan and nano-chitosan at the dose of 100 $\mu \mathrm{g} / \mathrm{kg}$ significantly reduced the mean percentage of excreted cysts up to 10 times in the infected BALB/C mice G. lamblia [14].

In the study conducted by Elmi et al. (2020), CNPs synthesized by Penicillium fungi at the dose of $50 \mu \mathrm{g} / \mathrm{ml}$ after $180 \mathrm{~min}$ exposure eliminated $31.3 \%$ of G. lamblia cysts [19]. Said et al. (2012) also showed that synthesized CNPs prepared by ionic crosslinking of chitosan solution at the dose of 5 ppm for 8 d significantly reduced the number of Giardia cysts in the stool and trophozoites in intestinal sections of rats with giardiasis [16].

Recently, El-Gendy et al. (2021) demonstrated that oral administration of CNPs at the dose of $50 \mu \mathrm{g} / \mathrm{hamster} /$ day for 7 consecutive days alone and especially in combination with MTZ in Syrian hamsters infected with $G$. lamblia significantly reduced the cysts and trophozoites counts by $63.64-94.69 \%$. They also reported significant healing of intestinal mucosa in the infected hamsters after treatment with MTZ+CsNPs [15] 
Table 1: A list of studies on effects of nanoparticles against giardiasis

\begin{tabular}{|c|c|c|c|c|c|c|c|}
\hline Nanoparticle & $\begin{array}{l}\text { Preparation } \\
\text { method }\end{array}$ & Condition & $\begin{array}{l}\text { Parasite } \\
\text { form }\end{array}$ & Dose & Time & Outcome & Ref \\
\hline $\begin{array}{l}\text { Chitosan } \\
\text { nanoparticles }\end{array}$ & - & In vitro & Cysts & $\begin{array}{l}50,100 \\
200 \text { and } \\
400 \\
\mu \mathrm{g} / \mathrm{ml}\end{array}$ & $\begin{array}{l}10,30 \\
60 \text { and } \\
180 \mathrm{~min}\end{array}$ & $\begin{array}{l}\text { CNPs) synthesized by Penicillium viridicatum and } P \text {. } \\
\text { aurantiogriseum at the doses of } 50,100,200 \text {, and } \\
400 \mu \mathrm{g} / \mathrm{ml} \text { on Giardia cysts; whereas CNPs at the } \\
\text { dose of } 400 \mu \mathrm{g} / \mathrm{ml} \text { and after } 180 \mathrm{~min} \text { exposure } \\
\text { killed } 100 \% \text { Giardia cysts }\end{array}$ & [13] \\
\hline $\begin{array}{l}\text { Chitosan and } \\
\text { nano-chitosan }\end{array}$ & $\begin{array}{l}\text { Ionic gelation } \\
\text { method } \\
\text { - }\end{array}$ & $\begin{array}{l}\text { In vitro } \\
\text { In vivo } \\
\text { (BALB/c } \\
\text { mice) }\end{array}$ & $\begin{array}{l}\text { Cysts and } \\
\text { trophozoi } \\
\text { tes }\end{array}$ & $\begin{array}{l}100,200 \\
400 \\
\mu \mathrm{g} / \mathrm{ml} \\
\text { And } 10 \\
50,100 \\
\mu \mathrm{g} / \mathrm{kg}\end{array}$ & $\begin{array}{l}30,60 \\
180 \\
\text { Min and } \\
24 \\
48,72 \mathrm{~h}\end{array}$ & $\begin{array}{l}\text { Chitosan and nano-chitosan at the concentrations of } \\
100,200 \text {, and } 400 \mu \mathrm{g} / \mathrm{ml} \text { significantly reduced the } \mathrm{G} \text {. } \\
\text { lamblia trophozoite ranging from } 89 \text { to } 100 \text { after } 3 \mathrm{~h} \\
\text { exposure in vitro; they findings also showed that the } \\
\text { oral administration of chitosan and nano-chitosan at } \\
\text { the dose of } 100 \mu \mathrm{g} / \mathrm{kg} \text { significantly reduced the mean } \\
\text { percentage of excreted cysts up to } 10 \text { times in } \\
\text { infected BALB/C mice } G \text {. lamblia }\end{array}$ & [14] \\
\hline $\begin{array}{l}\text { Chitosan } \\
\text { nanoparticles } \\
\text { (CNPs) }\end{array}$ & $\begin{array}{l}\text { Ionic gelation } \\
\text { technique } \\
\text { - }\end{array}$ & $\begin{array}{l}\text { In vivo } \\
\text { (Syrian } \\
\text { hamsters) }\end{array}$ & $\begin{array}{l}\text { Cysts and } \\
\text { trophozoi } \\
\text { tes }\end{array}$ & $\begin{array}{l}50 \mu \mathrm{g} / \mathrm{ha} \\
\mathrm{mster} / \mathrm{da} \\
\mathrm{y}\end{array}$ & $7 \mathrm{~d}$ & $\begin{array}{l}\text { CNPs, especially in combination with metronidazole } \\
\text { (MTZ) significantly reduced the cysts and trophozoites } \\
\text { counts from 63.64-94.69\%. Histopathological tests } \\
\text { demonstrated significant healing of intestinal mucosa } \\
\text { after treatment with MTZ+CsNPs. }\end{array}$ & [15] \\
\hline $\begin{array}{l}\text { Chitosan } \\
\text { nanoparticles }\end{array}$ & $\begin{array}{l}\text { Ionic cross- } \\
\text { linking and } \\
\text { spontaneous } \\
\text { emulsification } \\
\text { method }\end{array}$ & $\begin{array}{l}\text { In vivo } \\
\text { (Rats) }\end{array}$ & Cysts & $5 \mathrm{ppm}$ & $8 \mathrm{~d}$ & $\begin{array}{l}\text { CNPs significantly reduced the cysts and } \\
\text { trophozoites counts up to } 68.2 \text { and } 79.6 \% \text { in rats } \\
\text { infected with } G \text {. lamblia, respectively. }\end{array}$ & [16] \\
\hline $\begin{array}{l}\text { Curcumin } \\
\text { nanoparticles }\end{array}$ & $\begin{array}{l}\text { Ionic cross- } \\
\text { linking and } \\
\text { spontaneous } \\
\text { emulsification } \\
\text { method }\end{array}$ & $\begin{array}{l}\text { In vivo } \\
\text { (Rats) }\end{array}$ & Cysts & $450 \mathrm{mg}$ & $8 \mathrm{~d}$ & $\begin{array}{l}\text { CNPs significantly reduced the cysts and } \\
\text { trophozoites counts up to } 54.6 \text { and } 51.7 \% \text { in rats } \\
\text { infected with } G \text {. lamblia, respectively. }\end{array}$ & [16] \\
\hline $\begin{array}{l}\text { Gold } \\
\text { Nanoparticles } \\
\text { (AuNps) }\end{array}$ & (1) & In vitro & Cysts & $\begin{array}{l}0.05,0.1 \\
0.3 \\
\mathrm{mg} / \mathrm{ml}\end{array}$ & $\begin{array}{l}5,15 \\
30,60 \\
\text { and } 180 \\
\min \end{array}$ & $\begin{array}{l}\text { In this study, AuNps were used in vitro on Giardia } \\
\text { cysts isolated from stools. The results showed that } \\
\text { the lethal effect of these nanoparticles with a } \\
\text { concentration of } 0.3 \mathrm{mg} / \mathrm{ml} \text { in } 5 \mathrm{~min} \text { is } 62 \% \text { and in } \\
180 \text { min it reaches } 96 \% \text {. For this reason, it can be } \\
\text { said that AuNps at a concentration of } 0.3 \mathrm{mg} / \mathrm{ml} \\
\text { have a lethal effect similar to metronidazole. }\end{array}$ & {$[17]$} \\
\hline $\begin{array}{l}\text { Gold } \\
\text { nanoparticles } \\
\text { and Citrullus } \\
\text { colocynthis L. } \\
\text { nanoparticles } \\
\text { (nAu+nCc) }\end{array}$ & $\begin{array}{l}\text { Green } \\
\text { synthesis }\end{array}$ & $\begin{array}{l}\text { In vivo } \\
\text { (Swiss } \\
\text { Albino } \\
\text { Mice) }\end{array}$ & - & $20 \mu \mathrm{g}$ & $8 \mathrm{~d}$ & $\begin{array}{l}\text { In this study, the effect of combination therapy of } \\
\text { nAu+nCc in the animal model was investigated. } \\
\text { Experiments were performed on } 50 \text { Swiss Albino } \\
\text { Mice infected with Giardia cysts using a nasogastric } \\
\text { tube, and the results showed that combination } \\
\text { therapy eliminated } 93.2 \% \text { of Giardia trophozoites. }\end{array}$ & [18] \\
\hline Nano-chitosan & $\begin{array}{l}\text { Ionotropic } \\
\text { gelation } \\
\text { method }\end{array}$ & In vitro & Cysts & $\begin{array}{l}1,5,10 \\
20,40 \\
\text { and } \\
50 \mu \mathrm{g} / \mathrm{ml}\end{array}$ & $180 \mathrm{~min}$ & $\begin{array}{l}\text { In this study, Nano-chitosan obtained from } \\
\text { Penicillium waksmanii, } P \text {. aurantiogriseum, } P \text {. } \\
\text { viridicatum and P. citrinum were used. The results } \\
\text { show that the greatest effect of these nanoparticles } \\
\text { is at a concentration of } 50 \mu \mathrm{g} / \mathrm{ml} \text {, which has a lethal } \\
\text { effect of } 31.3 \% \text {, and in addition, it was found that } \\
\text { Nano-chitosan has little toxicity and side effects. }\end{array}$ & [19] \\
\hline $\begin{array}{l}\text { Selenium and } \\
\text { Copper Oxide } \\
\text { Nanoparticles } \\
\text { (CuO NPs and } \\
\text { Se NPs) }\end{array}$ & Purchased & In vitro & Cysts & $\begin{array}{l}0.15,0.3 \\
\text { and } 0.6 \\
\mathrm{mg} / \mathrm{ml}\end{array}$ & $\begin{array}{l}10,15 \\
30,60 \\
\text { and } 180 \\
\text { min }\end{array}$ & $\begin{array}{l}\text { In this study, the effect of CuO NPs and Se NPs with a } \\
\text { size of } 10 \text { to } 45 \mathrm{~nm} \text { on Giardia deudenalis cysts } \\
\text { obtained from patients' stools was investigated. The } \\
\text { results showed that CuO NPs at a concentration of } 0.6 \\
\mathrm{mg} / \mathrm{ml} \text { and Se NPs at a concentration of } 0.3 \mathrm{mg} / \mathrm{ml} \mathrm{had} \\
\text { a similar effect to metronidazole on cysts. }\end{array}$ & {$[20]$} \\
\hline $\begin{array}{l}\text { Silver } \\
\text { nanoparticles } \\
\text { (Ag NPs) }\end{array}$ & Purchased & $\begin{array}{l}\text { In vivo } \\
\text { (BALB/c } \\
\text { mice) }\end{array}$ & - & $100 \mu \mathrm{g} / \mathrm{g}$ & $\begin{array}{l}24,48 \\
\text { and } 72 \mathrm{~h}\end{array}$ & $\begin{array}{l}\text { In this study, the anti-Giardia ability of Ag NPs as a } \\
\text { combination therapy with metronidazole and alone } \\
\text { was investigated. Experiments showed that in } 72 \text { h of } \\
\text { combined treatment of Ag NPs and metronidazole has } \\
\text { an effect of } 83.30 \% \text { and the use of nanoparticles alone } \\
\text { has the same effect. But in } 24 \text { h the effect of Ag NPs is } \\
66.60 \% \text {, which is greater than the effect of } \\
\text { metronidazole. }\end{array}$ & [21] \\
\hline $\begin{array}{l}\text { Silver } \\
\text { nanoparticles }\end{array}$ & $\begin{array}{l}\text { Ionic cross- } \\
\text { linking and } \\
\text { spontaneous } \\
\text { emulsification } \\
\text { method and } \\
\text { green } \\
\text { synthesis }\end{array}$ & $\begin{array}{l}\text { In vivo } \\
\text { (Rats) }\end{array}$ & Cysts & $100 \mathrm{ppm}$ & $8 \mathrm{~d}$ & $\begin{array}{l}\text { CNPs significantly reduced the Giardia cysts and } \\
\text { trophozoites counts up to } 72.7 \text { and } 81.1 \% \text { in rats } \\
\text { infected with } G \text {. lamblia }\end{array}$ & [16] \\
\hline $\begin{array}{l}\text { Zinc oxide } \\
\text { nanoparticles } \\
\text { (ZnO-NPs) }\end{array}$ & Purchased & $\begin{array}{l}\text { In vivo } \\
\text { (BALB/c } \\
\text { mice) }\end{array}$ & - & $10 \mathrm{mg} / \mathrm{kg}$ & $7 \mathrm{~d}$ & $\begin{array}{l}\text { In this study, we investigated the effect of ZnO-NPs and } \\
\text { metronidazole on Giardia intestinalis-infected mice. } \\
\text { Studies have shown that ZnO-NPs in the mentioned } \\
\text { dose can kill } 93.7 \% \text { of cysts and also metronidazole in } \\
500 \mathrm{mg} / \mathrm{kg} \text { dose can kill } 99.2 \% \text { of cysts while combined } \\
\text { treatment with both The drug has a } 100 \% \text { result. }\end{array}$ & {$[22]$} \\
\hline
\end{tabular}


Curcumin is a natural polyphenol compound derived from turmeric root with various pharmacological properties [32]. It has many therapeutic properties such as anti-inflammatory, anti-cancer, antioxidant, and antimicrobial activity. Considering the antiparasitic activities of curcumin, reviews showed the potent efficacy of curcumin against some pathogenic species of Plasmodium, Leishmania, Trypanosoma, Schistosoma, and more commonly against other cosmopolitan parasites such as nematodes, Babesia, Giardia, and Coccidia [33]. In the study conducted by of Said et al. (2012), the results showed that curcumin nanoparticles synthesized by ionic crosslinking of curcumin solution at the dose of $450 \mathrm{mg}$ for $8 \mathrm{~d}$ significantly reduced the number of Giardia cysts $(54.6 \%)$ in the stool and trophozoites $(51.7 \%)$ in intestinal sections of the rats with giardiasis [16].

\section{Citrullus colocynthis nanoparticles}

Citrullus colocynthis is an herbaceous plant from the Cucurbitaceae family that contains pectin and alkaloids such as Elatyrene A and Elatyrisin B with various pharmacological properties such as antidiabetic, anti-cancer, anti-inflammatory, anti-oxidant, and antimicrobial properties [34, 35]. Recently, Al-Ardi et al. (2020) demonstrated that the oral administration of C. colocynthis nanoparticles at the dose of $20 \mu \mathrm{g}$ for $8 \mathrm{~d}$ significantly reduced the mean number of G. lamblia trophozoites by $93.2 \%$ in Swiss Albino mice with giardiasis [18].

\section{Inorganic nanoparticles}

\section{Gold}

Gold is one of the vital elements which is broadly used in various medical fields such as biochemistry, microbiology, immunology, and cytology. Gold nanoparticles have many applications in medicine, including biosensors, clinical chemistry, immunoassays, genomics, photothermolysis of cancer cell. They also have other effects such as analgesic, anti-angiogenesis, anti-HIV virus, and anti-parasites, including Plasmodium spp., Giardia spp., Leishmania spp., etc. [17, 18, 36, 3].

In the study conducted by Bavand et al. (2014), gold NPs were used at the dose of $0.05,0.1,0.3 \mathrm{mg} / \mathrm{ml}$ for $5,15,30,60$, and $180 \mathrm{~min}$ against G. lamblia cysts. Their results showed that gold NPs at the concentration of $0.3 \mathrm{mg} / \mathrm{ml}$ in $180 \mathrm{~min}$ were able to kill $96 \%$ of cysts [17]. In addition, the study conducted by Al-Ardi (2020) demonstrated that oral administration of gold nanoparticles at the dose of $20 \mu \mathrm{g}$ for 8 $\mathrm{d}$ significantly reduced the mean number of $G$. lamblia trophozoites by 93.2\% in Swiss Albino mice with giardiasis [18].

\section{Silver}

Silver nanoparticles are one of the unique materials that have special physical and chemical properties such as resistance to oxidation and high thermal conductivity and are used in various fields such as industry, health, and medicine. Various pharmacological properties, including anti-inflammatory, anti-cancer, antioxidant, anti-angiogenic, and antimicrobial activities, have been attributed to silver nanoparticles. Regarding the antimicrobial effects of silver nanoparticles, previous reviews have represented the antimicrobial effects of these nanoparticles on a wide range of microbial pathogens such as Escherichia coli, Candida species, and HIV virus and parasites such as Leishmania spp. and G. lamblia [21,38].

In the study conducted by Idan and Ardalan (2020) on BALB/c mice with giardiasis, it has been proven that use of silver nanoparticles at the dose of $100 \mu \mathrm{g} / \mathrm{g}$ reduced 83.30 and $66.6 \%$ of Giardia cysts after 72 and $24 \mathrm{~h}$, respectively. In another study conducted by Said et al. (2012), it was proven that silver nanoparticles obtained by green synthesis at the dose of $50 \mu \mathrm{g}$ for $8 \mathrm{~d}$ can reduce $72.7 \%$ of $G$. lamblia cysts in the mice with giardiasis [16].

\section{Selenium}

Selenium is a semi-solid metal that is classified as a trace element and was discovered as a byproduct of sulfuric acid synthesis. Many studies have studied the properties of this element, including antidiabetic, anti-cancer, antioxidant, and anti-inflammatory [39]. In addition, this element has various antimicrobial activities such as anti-viral, antibacterial, as well as anti-parasites effects against as
Entamoeba histolytica and Giardia spp. [20, 39]. In the study conducted by Malekifard and Tavassoli (2020), the results showed that selenium nanoparticles at various concentrations, particularly at the dose of $0.6 \mathrm{mg} / \mathrm{ml}$ after 10, 15, 30, 60, and $180 \mathrm{~min}$ incubation, killed $100 \%$ of $G$. deudenalis cysts in vitro [20].

\section{Copper oxide}

Copper oxide nanoparticles are the semiconductor compound with many applications such as in industrial catalyst, gas sensors, electronic materials, biomedicines, and environmental remediation $[40,41]$. In addition, it has been used as antimicrobial agents against some microbial pathogens such as Klebsiella pneumoniae, Pseudomonas aeruginosa, Entamoeba histolytica, and Cryptosporidium parvum, G. deudenalis [20, 42]. Considering the antiparasitic effects of copper oxide nanoparticles, Malekifard and Tavvasoli (2020) found these nanoparticles at various concentrations, particularly at the dose of $0.6 \mathrm{mg} / \mathrm{ml}$ after $180 \mathrm{~min}$ incubation, killed $97 \%$ of $G$. deudenalis cysts in vitro [20].

\section{Zinc oxide}

Zinc is one of the trace elements with different compounds which have various pharmacological properties [43]. Zinc oxide ( $\mathrm{ZnO}$ nanoparticles are a favorable compound for use in biomedical field, particularly given their anticancer and antimicrobial activities [44]. Considering antimicrobial effects of Zno NPs, previous studies have demonstrated these nanoparticles have potent antimicrobial properties against some of the pathogenic microbial strains such as Streptococcus pneumonia, Bacillus subtilis, Eimeria papillata, Leishmania spp., and Giardia spp. [45]. In the study by Reham et al. (2019), it was found that the use of ZnO nanoparticles at the dose of $10 \mathrm{mg} / \mathrm{kg}$ and for the period of $7 \mathrm{~d}$ alone could eliminate $93.7 \%$ of Giardia cysts in mice; if combined with metronidazole, it had $100 \%$ lethality [22].

\section{CONCLUSION}

The results of this review showed the high efficacy of a wide range of organic and non-organic NPs against giardiasis, indicating that nanoparticles could be considered as an alternative and complementary resource for treating giardiasis since they had no significant toxicity. In addition, we found no resistance formation against nanoparticles for giardiasis. However, more studies are required to elucidate this conclusion, especially in clinical systems.

\section{AVAILABILITY OF DATA AND MATERIALS}

All data generated or analyzed during this study are included in this published article.

\section{FUNDING}

Nil

\section{AUTHORS CONTRIBUTIONS}

All authors have contributed equally.

\section{CONFLICTS OF INTERESTS}

\section{Declared none}

\section{REFERENCES}

1. Lujan HD. Giardia and giardiasis. Medicina (B Aires) 2006;66:70-4.

2. Adam RD. Biology of giardia lamblia. Clin Microbiol Rev 2001;14:447-75.

3. Obulesu G, Ar H. A study of stool samples from hiv positive and hiv negative at Andhra Pradesh. Asian J Pharm Clin Res 2018;1:394-7.

4. Hooshyar H, Rostamkhani P, Arbabi M, Delavari M. Giardia lamblia infection: review of current diagnostic strategies. Gastroenterol Hepatol Bed Bench 2019;12:3-12.

5. Escobedo AA, Cimerman S. Giardiasis: a pharmacotherapy review. Expert Opin Pharmacother 2007;8:1885-902.

6. Tian HF, Chen B, Wen JF. Giardiasis, drug resistance, and new target discovery. Infect Disord Drug Targets 2010;10:295-302. 
7. Lalle M, Hanevik K. Treatment-refractory giardiasis: challenges and solutions. Infect Drug Resist 2018;11:1921-33.

8. Kingsley JD, Dou H, Morehead J, Rabinow B, Gendelman HE, Destache CJ. Nanotechnology: a focus on nanoparticles as a drug delivery system. J Neuroimmune Pharmacol 2006;1:340-50.

9. Nafari A, Cheraghipour K, Sepahvand M, Shahrokhi G, Gabal E, Mahmoudvand H. Nanoparticles: new agents toward treatment of leishmaniasis. Parasite Epidemiol Control 2020;10:e00156.

10. Albalawi AE, Alanazi AD, Baharvand P, Sepahvand M, Mahmoudvand $\mathrm{H}$. High potency of organic and inorganic nanoparticles to treat cystic echinococcosis: an evidence-based review. Nanomaterials 2020;10:2538.

11. Albalawi AE, Khalaf AK, Alyousif MS, Alanazi AD, Baharvand P, Shakibaie M, et al. Fe304@ piroctone olamine magnetic nanoparticles: synthesize and therapeutic potential in cutaneous leishmaniasis. Biomed Pharmacother 2021;139:111566.

12. Moher D, Liberati A, Tetzlaff J, Altman DG, Prisma Group. Preferred reporting items for systematic reviews and meta-analyses: the PRISMA statement. Ann Intern Med 2009;151:264-9.

13. Yarahmadi M, Fakhar M, Ebrahimzadeh MA, Chabra A, Rahimiesboei B. The anti-giardial effectiveness of fungal and commercial chitosan against Giardia intestinalis cysts in vitro. J Parasit Dis 2016;40:75-80.

14. Chabra A, Rahimi Esboei B, Habibi E, Monadi T, Azadbakht M, Elmi T, et al. Effects of some natural products from fungal and herbal sources on Giardia lamblia in vivo. Parasitology 2019;146:1188-98.

15. El-Gendy AM, Mohammed MA, Ghallab MM, Abdel Aziz MO, Ibrahim SM. Therapeutic effect of chitosan nanoparticles and metronidazole in the treatment of experimentally giardiasis infected hamsters. Iranian J Parasitol 2021;16:32-42.

16. Said DE, ElSamad LM, Gohar YM. Validity of silver, chitosan, and curcumin nanoparticles as anti-Giardia agents. Parasitol Res 2012;111:545-54.

17. Bavand Z, Gholami S, Honari S, Rahimi Esboei B, Torabi N, Borabadi H. Effect of gold nanoparticles on Giardia Lamblia cyst stage in in vitro. Arak Med Univ J 2014;16:27-37.

18. Al-Ardi MH. The uses of gold nanoparticles and Citrullus colocynthis L. nanoparticles against Giardia lamblia in vivo. Clin Epidemiol Glob Heal 2020;8:1282-6.

19. Elmi T, Rahimi Esboei B, Sadeghi F, Zamani Z, Didehdar M, Fakhar M, et al. In vitro antiprotozoal effects of nano-chitosan on Plasmodium falciparum, Giardia lamblia and Trichomonas vaginalis. Acta Parasitol 2021;66:39-52.

20. Malekifard F, Tavassoli KV M. In vitro assessment antiparasitic effect of selenium and copper nanoparticles on giardia deodenalis cyst. Iran Soc Parasitol 2020;15:411-7.

21. Idan EM, Ardalan NM. Introducing silver nanoparticles as antigiardial in experimentally infected mice. Ther Versus Toxicity 2020;11:701-8.

22. Reham M Brakat, Shaimaa A Sharaf EL-Deen HIAE. Zinc oxide nanoparticles kill giardia and protect against intestinal damage. Egypt J Med Microbiol 2019;28:95-103.

23. AlMohammed HI, Khudair Khalaf A, E Albalawi A, Alanazi AD, Baharvand P, Moghaddam A, et al. Chitosan-based nanomaterials as valuable sources of anti-leishmanial agents: a systematic review. Nanomaterials 2021;11:689.

24. Patel DP, Singh S. Chitosan: a multifaceted polymer. Int J Curr Pharm Res 2015;7:21-8.

25. Muxika A, Etxabide A, Uranga J, Guerrero P, de la Caba K. Chitosan as a bioactive polymer: processing, properties and applications. Int J Biol Macromol 2017;105:1358-68.

26. Wang $\mathrm{W}$, Meng Q, Li Q, Liu J, Zhou M, Jin Z, et al. Chitosan derivatives and their application in biomedicine. Int J Mol Sci 2020;21:487.

27. Ahmed TA, Aljaeid BM. Preparation, characterization, and potential application of chitosan, chitosan derivatives, and chitosan metal nanoparticles in pharmaceutical drug delivery. Drug Des Dev Ther 2016;10:483-507.

28. Cheraghipour K, Masoori L, Ezzatkhah F, Salimikia I, Amiri S, Makenali AS, et al. Effect of chitosan on toxoplasma gondii infection: a systematic review. Parasite Epidemiol Control 2020;11:e00189.

29. Rize BR, Younes NN, Rasool K, Nasrallah GK. Synthesis, bioapplications, and toxicity evaluation of chitosan-based nanoparticles. Int J Mol Sci 2019;20:5776.

30. Guan G, Azad AK, Lin Y, Kim SW, Tian Y, Liu G, et al. Biological effects and applications of chitosan and chitooligosaccharides. Front Physiol 2019;10:516.

31. Rozman NAS, Tong WY, Leong CR, Tan WN, Hasanolbasori MA, Abdullah SZ. Potential antimicrobial applications of chitosan nanoparticles (ChNP). J Microbiol Biotechnol 2019;29:1009-13.

32. Krishnamurthy G, Roy D, Kumar J. Curcumin, a natural golden drug and its anticancer aspects from synthesis to delivery: a review. Int J Appl Pharm 2020;7:70-84.

33. Cheraghipour K, Ezatpour B, Masoori L, Marzban A, Sepahvand A, Rouzbahani AK, et al. Anti-candida activity of curcumin: a systematic review. Curr Drug Discovery Technol 2021;18:379-90.

34. Satyavani K, Gurudeeban S, Ramanathan T, Balasubramanian T Biomedical potential of silver nanoparticles synthesized from calli cells of citrullus colocynthis (L.) schrad. J Nanobiotechnol 2011;9:43.

35. Hussain AI, Rathore HA, Sattar MZ, Chatha SA, Sarker SD, Gilani AH. Citrullus colocynthis (L.) schrad (bitter apple fruit): a review of its phytochemistry, pharmacology, traditional uses and nutritional potential. J Ethnopharmacol 2014;15:54-66.

36. Dykman LA, Khlebtsov NG. Gold nanoparticles in biology and medicine: recent advances and prospects. Acta Nat 2011;3:34-55.

37. Das M, Shim KH, An SSA, Yi DK. Review on gold nanoparticles and their applications. Toxicol Environ Health Sci 2011;3:193-205.

38. Zhang XF, Liu ZG, Shen W, Gurunathan S. Silver nanoparticles: Synthesis, characterization, properties, applications, and therapeutic approaches. Int J Mol Sci 2016;17:1534.

39. Rayman MP. Selenium and human health. Lancet 2012;379:1256-68

40. Ezzatkhah F, Khalaf AK, Mahmoudvand H. Copper nanoparticles: biosynthesis, characterization, and protoscolicidal effects alone and combined with albendazole against hydatid cyst protoscoleces. Biomed Pharmacother 2021;136:111257.

41. Albalawi AE, Abdel Shafy S, Khudair Khalaf A, Alanazi AD, Baharvand P, Ebrahimi K, et al. Therapeutic potential of green synthesized copper nanoparticles alone or combined with meglumine antimoniate (glucantime ${ }^{\circledR}$ ) in cutaneous leishmaniasis. Nanomaterials 2021;11:891.

42. Saadatmand M, Al-Awsi GR, Alanazi AD, Sepahvand A, Shakibaei M, Shojaee S, et al. Green synthesis of zinc nanoparticles using lavandula angustifolia vera. extract by microwave method and its prophylactic effects on Toxoplasma gondii infection. Saudi J Biol Sci 2021. https://doi.org/10.1016/j.sjbs.2021.07.007

43. Roohani N, Hurrell R, Kelishadi R, Schulin R. Zinc and its importance for human health: an integrative review. J Res Med Sci 2013;18:144.

44. Sirelkhatim A, Mahmud S, Seeni A, Kaus NH, Ann LC, Bakhori SK, et al. Review on zinc oxide nanoparticles: antibacterial activity and toxicity mechanism. Nano-micro Lett 2015;7:219-42.

45. Nadhman A, Nazir S, Khan MI, Ayub A, Muhammad B, Khan M, et al. Visible-light-responsive $\mathrm{ZnCuO}$ nanoparticles: benign photodynamic killers of infectious protozoans. Int J Nanomed 2015;10:6891-903. 